Council on Scientific Policy still stands. In his view that Council should be responsible not to the Lord President of the Council in his role as Minister for Science but to the Cabinet. That the point had been taken might follow from certain tentative arrangernents which the Prime Minister has already made for strengthoning the Cabinet Office. Meanwhile, it is to bo hoped that both inside and outside the Government new arrangements will be impartially assessed in the light of the momentous value of informed criticism.

\section{ORGANIZATION OF SCIENTIFIC ADVICE}

Scientists and National Policy-making

Edited by Robert Gilpin and Christopher Wright. Pp. viii +307 . (New York and London: Columbia University Press, 1964.) 7.50 dollars.

PART from a roview by Sir Solly Zuckerman and A comment by Dr. $\mathrm{S}$. Toulmin in Minerva on taking stock of the complexity of soientific choice, this collection of essays has attracted littlo attention in Britain, in spite of the stimulus to thinking about scientific policy given by the international ministerial meeting on science at the Paris headquarters of tho Organization for Economic Co-operation and Development in October 1963. Nevertholess, although primarily concerned with the making of policy in the United Statos, most of the essays are of even greater interest in the light of the new measures which the present Government has taken for the organization of civil science in Britain and to associate scientists with the formulation of policy. Whatever basis there may be for the suggestion that the new arrangements follow the Presidential structure, theso essays are, as Dr. Toulmin points out, a most useful contribution to the discussion of the general problom and to assessing the soundness of particular proposals.

A fow of the essays have already been published. These include D. K. Price's discussion of the nature and rolo of the scientific establishment in the United States; Prof. W. S. Sayres's "Scientists and American Science Policy"; and Prof. W. R. Schilling's "Sciontists, Foreign Policy and Politics". Apart, however, from R. N. Kreidler, who writes on "The President's Science Advisers and National Scienco Policy", and H. Brooks, who deals with the Scientific Adviser, it is not made cloar how far the authors are themselves writing from inside knowledge and association with the task of formulating policy and not simply from academic studies. Of the remaining essays, Prof. R. C. Wood contributes one on "Scientists and Polities: the Rise of an Apolitical Elite"; Prof. A. Wohlstetter writes on "Stratogy and the Natural Scientists" and B. Brodie discusses "The Scientific Strategists". Dr. C. Wright's "Scientists and the Establishment of Science Affairs", which concludes the book, makes an appropriate counterpant to the admirable introductory essay by his co-cditor, Prof. R. Gilpin, "Natural Scientists in Policymaking".

The essays thus range widely, though the common theme is clear and strong. Likewise, much of tho stimulus is derived from Sir Charles Snow's Godkin Lectures in 1960, and it differs from somo other American books in that the British contribution to the debate is reasonably reflected. Mr. Gilpin's introduction brings out very clearly the wny in which the participation of scientists in the formulation of policy in the Unitod States has developed in the past quarter of a century and the character of their contribution in relation to national support for seience and to national security. These questions are oxplored more fully in tho subsequent essays, but it is chiefly in those by Brodie and Wright, which diseuss the possibility that new types of expertise must be developed to cope satisfactorily with the problems now created by the intoractions of science, technology and society, that any essentially fresh contribution is made. By and large, the value of the symposium lies in prosenting in reasonable compass the position of presentday developments in this field in the United States and the trend of an important section of informed opinion.

Nevertheless, certain important points clearly emerge. If the crucial nature of the scientific contribution to national strength is manifest, too much is never claimed. Seientists in Government do not suggost that their advice should be overriding, but they do insist on the value and importance of scientific advice in reaching a balanced decision whero scientific issues are involved. This is not simply a matter of the arrangoments for tendering scientific advice or the calibro of the adviser: it is a matter also of public understanding, and herein lies the value of Christopher Wright's analysis of the bridges which in recent years have boen built between science and society. Tho implications of this essay deserve pon. dering, not simply by scientists or technologists as individuals but also by their professional associations. Thero is wide seope for croative thinking on this point to which the social scientist, as well as the physical scientist and the politician, has his own contribution to make. Moreover, as Harvey Brooks points out, the magnitude of scientific and technological entorprise to-day and tho influence which the scientific adviser already exerts on public policy expose the scientist to criticism which could be dangerous to science itself in the absence of public understanding. Scientists can no more afford to neglect to make the organization for advice as effective and efficient as possible than they can to promote publie understanding of the nature and limits of science. Nor are scientists likely to tender usable advice without some understanding of the nature and limitations of politics.

It is thus mainly for its constructive approach to the problems of the organization of scientific advice that the book is important. It does not ignore the question of the content of seiontific policy: the form of organization most appropriate can scarcely be detormined without reference to that content, to the purposes to be served. Although such roference, even in Christopher Wright's essay, is slender, it has wide implications for the scientist and is perhaps one of the most constructive foatures of a timely and stimulating book.

\section{SCOTLAND'S GREEN MANTLE}

\section{The Vegetation of Scotland}

Edited by Dr. John H. Burnett. Pp. xiii $+613+96$ plates. (Edinburgh and London: Oliver and Boyd, Ltd., 1964.) 126s.

THIS is an account of Scottish plant life in its environment, writton by the members of a group of ecologists and editod by Prof. J. H. Burnett, formerly of the University of St. Andrews and now of the Univorsity of Neweastle upon Tyne. Prof. Burnett contributes the introductory chapter, in which the history of plant ecology in Scotland is reviewod. The Perthshire brothers Robert and W. G. Smith, in the years immediately following 1898, laid the foundations of the study in Britain; the premature death of Robert, and his brothor's move to Leeds, directed the focus of activity south of the border, where its first major fruit was A. G. Tansley's Types of Rritish Vegetation (1911). In Scotland, Robert Smith's immediate successors soon disappeared from the scene and the early momentum was lost; the next thirty-fivo years produced only isolated papers of consequence on Scottish vegetation. Just after the Second World War the work of Gimingham, MeVean, Pooro and Ratcliffe stimulated a Scottish revival. 